\title{
ASPECTOS DA PESCA DA BALEIA NO BRASIL COLONIAL, (II).
}

(Continuação).

\section{IV. - AS ARMAÇõES.}

As armações no Brasil Colonial dos séculos XVII e XVIII, da Bahia até Santa Catarina. Inventários. Aparelhagem. Dependências. Pessoal: escriavos e assalariados. Funcionamento. Depoimentos coevos. Ruínas de uma armação.

Ao terminar o regime de estanque da pesca da baleia no Brasil, no início do século XIX, existiam as seguintes armações, cujo valor patrimonial, segundo inventário de 1801 , foi orçado em .... 176:424\$797 (1):

$\mathrm{Na}$ Bahia, a de Itaparica e a de Itapoã (2). A primeira erguia-se na ilha do mesmo nome, no Recôncavo baiano, em frente a Salvador, na Ponta da Armação das Baleias ou de Itaparica pròpriamente dita, e a segunda, ao norte da barra (3).

(1). - Pizarro e Araújo, op. cit, vol. 9 p. 265.

(2). - Pizarro e Araújo, op. cit., vol. 9, p. 264. Terminado o estanque da pesca da baleia, foram vendidas. Pizarra, op. cit., p. $265 \mathrm{diz}$ que foram construidas ainda outras armaçōes na Bahia cujos lucros não foram interessantes por constar a pesca de "gibartes", uma das espécies de baleias que rendem sòmente đe 8 a 10 barris de azeite, não sendo aproveitada a barbatana. Era então raro aparecer naquela região " $(\ldots)$ alguma baleia do mar do sul, mais rendosa em azeite e de barbatana servivel".

(3). - Luiz dos Santos Vilhena, "Recopilação de Notícias Soteropolitanas è Brasílicas...", vo1. I, "Carta Sexta", p 238. "Dentro do grande golpho da Bahia de Todos os Santos fica, além de muitas outras, tanto grandes como pequenas, a famoza ilha de Itaparida com sette legoas, com pouca differença de comprimento e menos de terça parte de largura.

Corre esta na direç̧ão Norte a Sul em que se contão quatro pontas mais notaveis, ou pera melhor dizer cinco, alem de outras de menos conta e vern a ser; a Ponta da Armação das Balêas, conhecida vulgarmente por Ponta de Itaparica; a ponta do Manguinho; a do Jaburu; a chamada das Agoas Mortas; a da Aratuba; e a de Caixa Pregos na extremidade da ilha do sul.

Entre esta itha e a terra firma ao Leste, em que fica a cidade, corre hum braço de mar por onde se entra para a Bahia com a largura de tres e meya para quatro legoas (...)". Na "Carta Primeira", diz Vilhena, à p. 42, "comprehende tãobem o termo de cidade a Itha de Itaparica que the fica de fronte (...)". "Na sua ponta do Norte que na distancia de cinco legoas fica fronteira á cidade, se acha a fortaleza de $\mathrm{S}$. Lourenço (...) e huma povoaçäo de bastante commercio no tempo da pescaria das Balleas, por ser naquelle citio a Fabrica onde se faz o azeite destes monstros marinhos. 
Nas armações da Bahia, postos aparelhados para a pesca da baleia e localizados à beira mar existiram em Itapoã, Pituba (Rio Vermelho), junto ao forte de Santo Antônio da Barra, Gambôa, Pedra Furada, Caravelas, Manguinho, Pôrto dos Santos e Barra do Gil; os três últimos na Ilha de Itaparica. Os de Manguinho, Pôrto dos Santos, Itapoã e Caravelas, apesar da decadência da pesca da baleia devido à escassez do animal e à falta de proteção do Estado, ainda conseguiram manter-se até o fim do século XIX e início do seguinte (4).

No litoral fluminense foram construídas a armação dos Búzios, na costa de Cabo Frio (5), a de São Domingos, do distrito da Vila Real da Praia Grande, hoje Niterói (6) e a da Ilha Grande (7).

Mais ao sul, no litoral paulista, funcionaram as armações da Ilha de São Sebastião e a da Bertioga, esta na barra da Vila de Santos, fundada por Silvestre Correia (8) em Santa Catarina, a armação Grande ou da Piedade, estabelecida aproximadamente em 1746 e situada no continente, à entrada da baía, ao norte da Ilha de Santa Catarina, no distrito da freguesia de São Miguel (9), a da Lagoinha, datando de 1772 , junto à lagoa do mesmo nome, na costa oriental da Ilha de Santa Catarina (10), a de Itapocoróia, esta-

Conthem a Ilha duas freguesias e são a de Santa Vera Cruz e a de Santo Amaro". No fim do século XVIII, estava a Ilha " (...) povoada de muitas Fazendas e Lavouras (...)", "Carta Primeira", p. 31.

Diz ainda Vilhena, referindo-sé ao outro local de pesca da baleia na Bahia: " $(.$.$) a Baleia, peixe monstruoso, de que todos tem noticia, a qual$ se pessa dentro nesta Bahia, e fora della, junto a Itapoan e dellas se faz azeite que faz hum dos ramos do Real contracto; (...)", vol. II, "Carta Vigesima", p. 733 .

Martius, quando esteve em Itaparica, na segunda década do século XIX, fala nas refinações de azeite de baleia "muito pequenas e sem as instalaçóes adequadas". "Viagem pelo Brasil" $J, B$, von spix e C. F. P. von Martiurs, pp. 273 e 276 (nota II).

(4). - J. Teixeira Barras' "A Pesca da Baleia na Bahia", Revista do Instituto GeoGráfico e Histórico da Bahia", Ano VII, vol. VI, n 23, 1900, pp. 332, 335.

O Autor fala em "contrato da armaçāo" sem definir o conceito da expressão. Certamente foi um pôsto baleeiro, prolongamento da armação e dela dependente, sendo destinado à pesca, ao retalhamento da baleia e à obtenção do azeite.

(5). - Pizarro e Araújo, op. cit., vol. 2, p. 140. Outras deveriam ter existido em Cabo Frio, Rio de Janeiro e Ilha Grande.

Idem vol. 9.0, p. 260. A Armação dos Búzios ficava na Ponta dos Búzios, quatro léguas e meia ao Nornordeste de Cabo Frio. Aires de Casal, "Corografia Brasílica", tomo II, p 19.

(6). - Revista do Instituto Histórico e Geográfico Brasileiro, tomo LXII, płarte II, p. 186. "Armações da Pesca da Baleia", por Luís de França Almeida e Sá. Trabalho elaborado em 1899 na Secção do Tombamento dos Próprios Na. cionais.

(7). - Pizarro e Araújo, op. cit., vol. $9.0^{\circ}$ p. 260.

(8). - Pizarro e Araújo, vol. 9.0, pp 260 e 261.

(9). - Tinha por orago a Capela de Nossa Senhora da Piedade. Pizarro e Araújo, op. cit., vol. 9.\%, p. 268 . Ver Paula José Migurel de Brito. "Memória Política sôbre a Capitania de Santa Catarina..." p. 102, nota 7 .

(10). - Pizarro e Araújo, vol 9.0, pp. 242 e 268. Tinha Santa Ana por titular da sua capela. Foi fundada a armação obedecendo a provisão de 9 de julho de 1772. L. A. Boiteux, op. cit. p 5. Paulo José Miguel de Brito, op. cit., p. 102 . 
belecida em 1778, ao norte do rio Itajaí (11), a de Garupaba, fundada em 1793 ou 1795, no continente, ao sul do rio Embaú, junto ao Morro de Garupaba (12) (13), a de Imbituba, erguida em 1796, no têrmo da vila de Laguna (14), ao sul da antecedente (15).

Existiu, também, uma armação no litoral de Pernambuco. Em meados do século XVIII, tanto esta como as da Bahia, encontravam-se danificadas. A pesca da baleia tornara-se diminuta na região e de tal maneira que chegou mesmo a ser necessário suprir aquelas capitanias com o azeite fabricado no Rio de Janeiro (16).

Dirigia a indústria da baleia em cada armação da Bahia o Feitor-mor ou Administrador de todo o serviço e da fabricação do azeite. A êle encontravam-se subordinados operários especializados, tais como o Feitor da praia, encarregado da fiscalização e da venda da carne da baleia, o Mestre dos Facões que orientava o corte da carne para a separação do toicinho, o Mestre das Faquinhas incumbido do corte da carne e separação dos ossos; Facões, homens cuja tarefa era o "desmancho" da baleia, o corte de grandes talhos de toicinho e de carne do maxilar inferior, das "pás", cabeça e cauda ou "tôco", Faquinhas que separavam a carne dos os$\operatorname{sos}(17)$.

Pela observação dos bens pertencentes à Armação de São Domingos, construída onde hoje se ergue Niterói, no Rio de Janeiro, é possível imaginarmos o que era e o que continha uma armação de pesca de baleia do Brasil Colonial.

Datando de 1782, a Armação de São Domingos passou para a Fazenda Nacional em 1826, pela quantia de 109:658\$690. Foi então feito o expressivo inventário, que constou do seguinte:

"Alfaias da Capella em prodigiosa quantidade, numeroso e variado sortimento de vazilhame (no qual se destacavam 30 grandes caldeiras de puro cobre), 13 lanchas e catraias com os respectivos apetrêchos, o bergantim "Providencia" perfeitamente municiado, 25 escravos, fer-

11). - Pizarro e Araújo, op. cit., p. 268. O orago de sua Capela era São João Ba tista. Ao norte da de Itapocotóia, em 1807, foi fundada mais uma armação junto à barra grande do rio de Säo Francisco, na Ilha da Graça, por ordem da Junta da Fazenda Real do Rio de Janeiro. Idem, ibidem. Paulo José Miguel de Brito, op. cit., p. 102

(12). - Pizarro e Araújo, op. cit,, p. 268. A Capela èra dedicada a São Joaquim. Paulo José Miguel de Brito, op. cit., p. 102.

(13). - Pizarro e Araújo, op cit., p. 234.

(14). - Piżrro e Araújo, op. cit. p. 268.

(15). - Pavilo José Miguel de Brito, op. cit., p. 102

(16). - Departamento do Arquivo do Estado de Sāo Paulo. Livro Manuscrito 169 Tempo Colonial: "Avisos e Cartas Régias - 1765-1767", fls. 59 - Anexo: "Condiçoens do Contrato da Pescaria das Baleyas nas Costas do Brazil, e Ilhas a ellas adjacentes arrematado na Secretaria de Estado dos Negocios da Marinha e Dominios Ultramarinos a Ignacio Pedro Quintella e Companhia (...)". Impresso, 1765.

(17). - "A pesca da balêa na Provincia da Bahia", in Antônio Alves Câmara "Pescas e Peixes da Bahia", p. 53; p 63. Transcriçāo integral de um artigo publicado na "Revista da Sociedade de Geografia do Rio de Janeiro", tomo V, 1889. 
ragens para os differentes usos e serviços da Armação, muito material depositado, moveis e azeite de baleia em quantidade.

E em prédios:

Uma Capella, casa do Administrador, sobrado servindo de Fabrica do spermacete, casa dos tanques, casa de vender azeite, casa dos baleeiros, casa do engenho, casa do grande tanque, casa do guindaste, casa do ferreiro, casa do capellão, casa do feitor, casa do cirurgião, casa de banho, casa das senzallas dos escravos, armazem para as lanchas, armazem das amarras, ferraria, tanoaria, armazem das barbatanas, armazem das ferragens para os carros, enfermaria, pharmacia, armazem da Misericordia, caes, cercas de pedras, fontes d'água e seus encanamentos, e um grande armazem junto á casa do Administrador $(\ldots) "(18)$.

Na segunda metade do século XVII, existia uma armação na Ilha das Baleias "de fronte" à cidade de São Sebastião do Rio de Janeiro. Teria sido possivelmente na Ilha Grande ou Gipóia, no litoral fluminense, ao sul da baía de Guanabara (19).

Lá esteve, em julho de 1678, o Desembargador sindicante, Doutor João da Rocha Pitta, com o Provedor e o Escrivão da Fazenda Real, respectivamente, Pedro de Souza Pereira e Francisco da Costa Moura, para superintender uma avaliação dos bens da referida armação.

Terminava o contrato de Francisco Vás Graces. O novo arrematante era Manuel Cardoso Leitão que arrendava o contrato da pesca das baleias por um triênio (20).

(18). - "Armações da Pesca da Baleia", pờ Luís de França Almeida e Sá, op. cit., pp. 186 e 187 .

(19) . - Pizarro e Araújo op. cit., vol. $9 \circ$, p. 260 , afirma ter existido uma armação de baleias na Ilha Grande, no século XVII, certamente fundada pelo negociante Braz de Pina, quando fundou as de Cabo Frio e Rio de Janeiro. Dela não restaram vestígios.

A Ilha Grande fôra doada por Martim Afonso de Sousa ao Doutor Vicente da Fonseca. por Carta lavrada a 24 de janeiro de 1559 (Pizarro Araújo, op. cit., vol. 2.0, p. 209).

Quanto às referências à Ilha da Gipóia, de uma légua de comprido e um quarto de largo, diz a tradição que lá existiu uma armação e houve pesca de baleia (Pizarro e Araújo, op cit. vol. $20^{\circ}$,p. 73 ).

(20). - Documentos Históricos, vol. XXVII, pp. 209 e segtes. "Registo do traslado da posse que por conta de Sua Aíteza que Deus guarde tomou no Rio de Janeiro o Desembargador Syndicante o Doutor João da Rocha Pitta na Fabrica da pesca das Baleias". Datado da Ilha Das Baleias, a 6 de julho de 1678. Com documentos anexos: "Rol da fabrica que tem a armação dado por - arrendador Francisco Vás Graces", p. 211; "Fé das Citações", p. 215; "Termo de Louvamento", p. 215; "Juramento dos Louvados", p. 216; "Termo", p. 216; "Escravos da dita Fabrica" p 217; "Fabrica dejta armação", p. 219; "Arbitramento", p. 224; "Requerimento do Arrendador", p. 225; "Resoluçāo sobre o pagamento dos donos da fabrica", p. 226. A última data é: Bahia, novembro, 22 de 1679 . O registro foi feito a 5 de dezembro.

Quanto ao Juiz Sindicante, Doutor João da Rocha Pitta, teria sido tioavô de Sebastião da Rocha Pitta, o autor da "Historia da America Portugueza". Ver a "Noticia Biographica" de J. G. Goes inserta na obra, pp. IX e X. 
Importante para o nosso estudo é a avaliação feita. Importante não só pelas minúcias que apresenta no tocante ao material técnico de trabalho de que dispunha uma armação, como pelas referências à mão de obra e aos preços dos utensílios e dos escravos na segunda metade do século XVII no Rio de Janeiro.

Quanto aos escravos eis o seguinte:

\section{"Escravos da dita Fabrica"}

"Antonio Gomes mulato arpoador, e sua mulher Martha, também mulata que terá trinta annos e o arpoador cincoenta annos avaliado em cento e trinta mil reis, e a mulata em setenta mil reis que ambos fazem duzentos mil reis ...

Pascoal do gentio de Guiné de idade que pareceu de cincoenta annos avaliado em cincoenta $\mathrm{e}$ cinco mil reis ....................... Juliana do mesmo gentio mulher do dito Pascoal de idade que pareceu de quarenta e cinco annos com chagas avaliada em quarenta mil reis ............................

Pascoa filha dos negros acima crioula de idade que pareceu de trinta annos com uma cria por nome Pascoal de um anno avaliada mãe e cria em sessenta mil reis ..................

Maria crioula tambem filha de Pascoal de idade que pareceu de vinte anos avaliada em cincoenta mil reis .......................

Simão crioulo filho tambem de Pascoal de idade que pareceu de dez annos avaliado em trinta mil reis $\ldots \ldots \ldots \ldots \ldots \ldots \ldots \ldots \ldots \ldots$.

Mandú Aristondo do gentio de Guiné de idade que pareceu de cincoenta e oito annos avaliado em cincoenta mil reis .............

Maria Aristondo pequena mulher do dito negro Mandú que pareceu de sessenta annos doente avaliada em trinta mil reis .........

Manuel Songo do mesmo gentio de idade que pareceu de cincoenta e cinco annos avaliado em quarenta e cinco mil reis ...............

Antonica do mesmo gentio mulher do dito Manuel Songo de idade que pareceu de trinta annos com uma cria por nome Anna de um anno, avaliada mãe e cria em cincoenta mil reis

Garcia do mesmo gentio de idade que pareceu de quarenta annos avaliado em cincoenta (...) e cinco mil reis .....................

Maria Moenga do mesmo gentio de idade que pareceu de cincoenta annos avaliada em quarenta mil reis $\ldots \ldots \ldots \ldots \ldots \ldots \ldots \ldots$

Amaro do gentio de Guiné de idade que pareceu de cincoenta (...) annos avaliado em cincoenta mil reis ........................

$200 \$ 000$

$55 \$ 000$

$40 \$ 000$

$60 \$ 000$

$50 \$ 000$

$30 \$ 000$

$50 \$ 000$

$30 \$ 000$

$45 \$ 000$

$50 \$ 000$

$55 \$ 000$

$40 \$ 000$

$50 \$ 000$ 
Pedro Monjolo de idade que pareceu de trinta annos doente de um braço avaliado em cin-

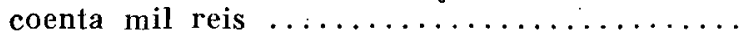

Gaspar do gentio de Guiné de idade de trinta annos avaliado em cincoenta mil reis ..

Mandú crioulo moleque de idade de dezesseis annos avaliado em (...) quarenta e cinco

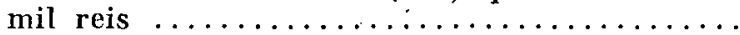

Felipa crioula de idade que pareceu de trinta e cinco annos avaliada em quarenta e cinco mil reis $\ldots \ldots \ldots \ldots \ldots \ldots \ldots \ldots \ldots$

Maria Piloto de idade que pareceu de sessenta e tantos annos avaliada em trinta mil reis

Joanna Cabo Verde de idade que pareceu mais de cincoenta annos doente avaliada em trinta e cinco mil reis $\ldots \ldots \ldots \ldots \ldots \ldots \ldots \ldots$

Bastião muito velho avaliado em dezesseis mil reis

Sôbre o material da armação e construções:

"Fabrica desta armação".

Quatro lanchas de arpoar Baleias usadas tres a dezoito mil reis cada uma, e uma mais velha por sete mil reis com suas velas, e mastros em sessenta e um mil reis ............

Um Batel velho em quatro mil reis .....

Quarenta e um remos bons, e velhos avalia-

dos todos em sete mil e quatrocentos reis

Uma (...) amarreta de linho que poderá

ter quińtaes e meio em dezoito mil reis .... Uma amarra nova de embé em oito mil reis Uma amarra velha de embé em dois mil reis Quatro betas de embé a pataca somma mil

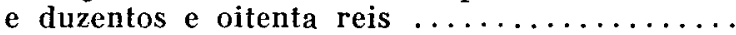
Tres cabrestantes velhos avaliados todos tres em seis mil reis

Uma espia de linho já velha que terá mais

de dois quintaes em oito mil reis ......... Uma estacha de barbante avaliada em quatro mil reis

Doze vioneiras de arpāo novas, e velhas

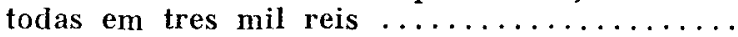
Onze vioneiras de lança e medianas em tres reis $\ldots \ldots \ldots \ldots \ldots \ldots \ldots \ldots \ldots \ldots$ Vinte lanças e medianas velhas em seis mil e

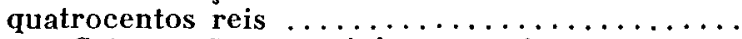
Sete arpóes a quinhentos reis somma tres mil e quinhentos reis

Tres fateixas uma nova, e as duas velhas avaliadas todas em oito mil e quinhentos .... Onze facas de chacotear velhas avaliadas em mil e novecentos e vinte reis .......... Doze facas de despir o peixe avaliadas em

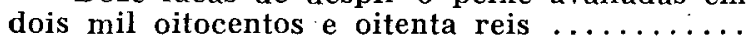


Vinte e sete Bicheiras de Chacotear avaliadas em mil seiscentos e vinte reis ......... Dezoito Bicheiras de praia avaliadas em mil seiscentos e vinte reis .............. A fateixinha de rosega avaliada em trezen-

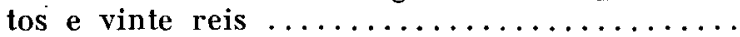

Quatro ferros de fazer cordas com carro tudo avaliado em mil duzentos e oitenta reis . Um grilhão com oito elos uma farropea $\mathrm{e}$ duas pegas tudo avaliado em dois mil e seis-

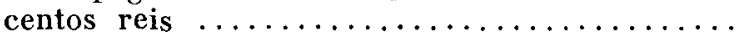

Duas raspadeiras uma zangaladeira em duas

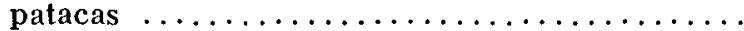

Um veio de roda uma enxó de mão, outra de martello, um martello, uma verruma grande, dois ferros de cortar, um de calafetar, uma verruma de encaibrar, outra de encaixar, uma balança de ferro pequena com conchas de páu, duas macetas de calafetar tudo muito velho avaliado em dois mil e quinhentos e sessenta reis

Uma alavanca, dois ganchos de despir peixe avaliado em mil quatrocentos e quarenta reis

Quatro barris pequenos de agua da gente em mil duzentos e oitenta reis ..............

Trinta mãos de estopa de linho a cincoenta reis são mil e quinhentos $\ldots \ldots \ldots \ldots \ldots \ldots \ldots$

Um aguilhão pequeno, e uma bala de ferro que serve de peso em trezentos e vinte reis

Dez enxadas velhas, sete machados, seis foices de roçar tudo velho, e avaliado em cinco mil e quinhentos e oitenta reis .............

Quatro frigideiras de cobre de frigir azeite uma com nove arrobas, e as tres mais pequenas a sete arrobas cada uma fazem novecentas e sessenta libras, a pataca a libra são trezentos e sete mil e duzentos reis ...........

Tres pombas (bombas?) duas escumadeiras de cobre que terão vinte e quatro libras a pataca a libra são sete mil seiscentos e oitenta reis

As casas do Engenho com as obras de pedreiro e carpinteiro, e mais casas que ha na dita armação de recolher azeites com fornalhas, e telha de fora tudo avaliado em novecentos mil reis com guindastes ..................

Nove tinas e quatro panicus, e seis paviolas tudo velho em quatro mil reis ............

Duas bicas uma por onde vem o azeite de receber, e outra para passar o azeite para os tanques tudo avaliado em oito mil reis ........

Dois coxos, em que levará sete pipas, e outros nove já velhos avaliados em dezesseis mil

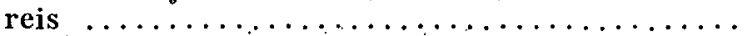

Uma canôa pequena que serve de deitar azeite em quatro mil reis . . . . . . . . . . . . . .

$900 \$ 000$ 
Tres tinas que servem de despejar borras a duzentos reis são seiscentos reis ...........

Dois tanques grandes, um na casa da tejuca e outro por detrás da casa de caldeiras avaliados ambos em cento, e vinte mil reis ......

Uma canôa grande que chamam a tejuca velha avaliada em vinte e cinco mil reis .......

Outra canôa grande na casa da varanda que serve de azeite avaliada em dezesseis mil reis

Outra canôa que serve de azeites na casa de sapé avaliada em doze mil reis .........

Outra canôa na casa dos tanques avaliada

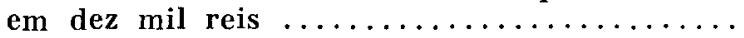

Outra canóa que serve de cortar o peixe muito velha avaliada em quatro mil reis ....

Cincoenta pipas a quatrocentos reis são vin-

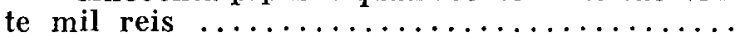

Doze barris que servem de trazer azeite á cidade a pataca um são tres mil, e oitocentos

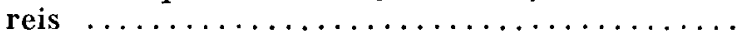

Quatorze taboas de tapinhoan para as lan-

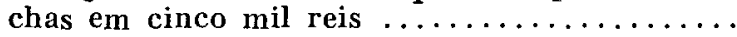

Duas taboas de Copaiba para concertar os panicus em seiscentos e quarenta reis ........

Quatro taboas de caixão em quinhentos reis

Quatro barcadas de lenha a tres mil e duzentos reis cada barcada somma doze mil e oitocentos reis $\ldots \ldots \ldots \ldots \ldots \ldots \ldots \ldots \ldots \ldots$

Quatro pipas mais em mil e seiscentos reis

Quatro candieiros dois de cobre, e dois de ferro avaliados todos em tres mil e duzentos reis

Mil piroleiras vasias, e velhas que servem de despejo do azeite a oitenta reis cada uma somma oitenta mil reis .................

Duas frigideiras novas de cobre com dezoito arrobas a cruzado a libra, somma duzentos e trinta mil e quatrocentos reis ..............

Umo barca usada com sua vela, e remos com o mais apparelho avaliada em quarenta mil reis

A "Fábrica" com os escravos foi avaliada em 3:045\$400, a saber, "as peças" 1:042\$000, a "Fábrica", 2:003\$400.

Tôda esta

“(...) fabrica escripta e avaliada neste Inventario recebeu o arrendador que de presente é da dita pesca Manuel Cardoso Leitão (...)" 
que se obrigou, quando terminasse o seu contrato, a entregar tudo conforme recebera (21).

A armação das baleias da Ilha de São Sebastião, no litoral paulista, localizava-se a duas léguas da vila do mesmo nome, na ponta leste da ilha, chamada "as canavieiras". Tinha uma Capela, dedicada a Nossa Senhora da Conceição, um administrador, um cirurgião, um feitor e os escravos necessários às atividades relativas à pesca da baleia e à obtenção do azeite. Situava-se, territorial e administrativamente, na Segunda Companhia de Ordenanças da Ilha.

Em 1785 era administrador daquela armação, o Capitão Amaro Gomes, homem de 57 anos de idade. Os feitores, Francisco Antônio Soares, de $\mathbf{3 0}$ anos e Salvador da Silva Aguiar, de 28.

Trabalhavam na armação 75 escravos, pertencendo seis ao Administrador e dois aos Feitores (22).

Curiosa é a Lista dos Escravos e mais pessoas que tem a armação das Baleas desta Va. de que he ademenistrador o Capm. Amaro Gomes (23).
Nome
Idade Nome
Idade

$\begin{array}{llll}\text { Añtonio Guiné } & 65 & \text { Antonio dito } & 60 \\ \text { Manoel dito } & 64 & \text { Joze dito } & 78 \\ \text { Manoel dito } & 50 & \text { João dito } & 60 \\ \text { Joaquim dito } & 40 & \text { Pedro Mina } & 45 \\ \text { Felipe dito } & 42 & \text { Manoel dito } & 70 \\ \text { Ignacio crioulo } & \mathbf{2 5} & \text { Manoel dito } & \mathbf{4 0} \\ \text { Francisco de Guiné } & 35 & \text { Joze dito } & \mathbf{5 5} \\ \text { Simão dito } & 45 & \text { Andre dito } & 62 \\ \text { Ventura dito } & 52 & \text { Salvador dito } & 70 \\ \text { Salvador dito } & 60 & \text { Domingos dito } & 30 \\ \text { Manoel dito } & 40 & \text { Miguel dito } & 32 \\ \text { Pedro dito } & 50 & \text { Joaquim dito } & 30 \\ \text { Matheus dito } & 70 & \text { Pedro dito } & 40 \\ \text { Jorge dito } & 56 & \text { Joze dito } & 35 \\ \text { João dito } & 64 & \text { Belcheor dito } & 35 \\ \text { Domingos dito } & 68 & \text { Raimundo dito } & 62 \\ \text { Antonio dito } & 69 & \text { Salvador dito } & 7 \\ \text { Sebastião dito } & 67 & \text { Joze dito } & 28 \\ \text { Francisco dito } & 56 & \text { Amaro dito } & 38 \\ \text { Dionizio dito } & 50 & \text { Matheus dito } & 28 \\ \text { Roque dito } & 38 & \text { Miguel dito } & 25 \\ \text { Gonçalo dito } & 29 & \text { João dito } & 24 \\ \text { Francisco dito } & 29 & \text { Lourenco dito } & 10 \\ \text { Caetano Guiné } & 28 & \text { Ifigenia } & 40\end{array}$

(21). - Documentos Históricos, vol. XXVII, loc. cit., pp. 217 a 224.

(22). - Departamento do Arquivo do Estado de São Paulo. Maço de População de São Sebastião, Tempo Colonial - 1765-1797, "Lista Gera1 dos habitantes da Villa de São Sebastião de que he Cappm. Mor Manoel Lopes da Ressurreição (...), de 1785 . (Manuscrito Inédito).

(23). - Departamento do Arquivo do Estado de São Paulo. "Lista Geral dos habitantes da Villa de São Sebastião (...) de 1785", (loc. cit.). 
"Nome

Antonio dito

Alberto dito

Belxior dito

Francisco dito

Domingos dito

Pedro dito

Antonio dito

Domingos dito

Miguel dito

Domingos dito

Pedro dito

Manuel Crioulo
Idade

30

36

25

24

27

28

29

30

30

29

32

12
Idade

60

20

15

14

9

5

\section{Escravos do Administrador}

Antonio de Guiné

Manoel dito

Caetano dito

Francisco Cabra
22

20

Domingos dito

\section{Escravos dos Feitores}

Antonio dito

45

A armação da Bertioga, que possuia uma sucursal no continente, estabelecida na Praia do Góis, ergueu-se na parte norte da Ilha. de Guaíbe ou Santo Amaro, junto ao Forte São Filipe e à velha Igreja, Santo Antônio de Guaíbe, mais tarde, Santo Antônio da Armação (24) de que hoje só restam ruínas.

Os estabelecimentos, em grande parte, achavam-se voltados para o Canal da Bertioga - entre o Continente e a Ilha de Santo Amaro - e para o "mar largo", beirando a "costa brava" (25).

O inventário feito a 17 de abril de 1789 da Armação da Bertioga é também bastante significativo.

Naquele ano, possuia:

"Uma Capélla e pertences no valor de

$2: 027 \$ 526$

Uma casa de sobrado

$1: 232 \$ 548$

Uma casa servindo de armazem

$610 \$ 775$

A casa dos tanques de azeite

$2: 709 \$ 269$

A casa do Engenho

$1: 046 \$ 203$

3 casas para amarras e lanchas

(24). - Francisco Martins dos Santos, "Bertioga Histórica e Legendária", pp. $36,37$.

(25). - Tinha a Armação de Santo Antônio da Bertioga "(...) Media Legoa de testada, e outro tanto de fundo (...) parte de um lado com o rio da barra da Bertioga, o mar largo e costa brava (...)".

Quanto à sucursal na praia do Góis, media "Setecentas braças de testada e trezentas de fundo, aguas vertentes para a entrada da Barra Grande, parte de um lado com terras da Fortaleza de Santo Amaro, e de outro com terras do Icanhema e Issangaba (...)", da "Relação das Terras, sitios ou Fazendas comprehendidas no distrito ou repartição da Villa e Praça de Santos", publicada na "Revista Nacional", vol. I, julho a setembro de 1877, Anno I, Santos - Apud Francisco Martins dos Santos; op. cit., pp. 41 e 42. 
A casa dos Feitores

$785 \$ 167$

A casa dos Baleeiros

$629 \$ 936$

30 senzalas para escravos

$28 \$ 800$

Uma fonte d'agua

$15 \$ 500$

Um caes de pedra

As cazas dos baleeiros da barra

$1: 331 \$ 088$

$350 \$ 892$

Caldeiras e instrumentos da pesca

$2: 067 \$ 695$

Ferragens de varios usos

$107 \$ 070$

Ferramentas de carpinteiros

Idem de tanoeiro e calafate

$12 \$ 680$

$15 \$ 690$

Objectos de bronze

3 saveiros

4 lanchas

2 canôas grandes

11 ditas pequenas

$65 \$ 760$

$345 \$ 600$

$120 \$ 600$

$106 \$ 400$

$108 \$ 420$

Abundante material

$456 \$ 830$

63 escravos

$3: 746 \$ 800$

Total

$18: 440 \$ 543 "(26)$.

Em 1765, um feitor da Armação da Bertioga recebia $25 \$ 600$ por ano. E' o caso de Antônio Joseph đe Souza, de 42 anos de idade, solteiro, que vivia (28) .

“(..) de feytor da Armação das Baleas (..)" (27),

As armações de Santa Catarina possuiam:

"Capella, cemiterio, hospital, botica, casas para cirurgião, feitor, administrador e capellão, tanques e escravatura; paiol, engenho, atafona e olaria; fornos e officinas em não pequeno numero; carretas, barcos, lanchas e canoas; trapiche, rampas e caes de pedra; ferragens, madeiras, gados, escravos, moveis, terras e grandes plantações, inclusive a do café".

A armação da Piedade tinha de frente 1990 braças ou quase 2/3 de légua. A de Itapocoróia, 1100 braças (29).

\footnotetext{
(26). - "Armações da Pesca da Baleia", por Luís de França Almeida e Sá, loc. cit., pp. 188 e 189. Esta soma foi o preço que custou a armação à Fazenda Real, de acôrdo com a 7a. condição da arrematação, segundo a conclusão do inventário em 1789.

(27). - Departamento do Arquivo do Estado de São Paulo. Maço de População de Santos. Tempo Colonial - 1765-1799. "Listas gerais da ordenança das Villas desta Capitania. Vila de Santos - 1765". (Manuscrito Inédito).

(28). - Ainda no litoral paulista, parece ter existido uma armação na Ilha do Bom Abrigo, ao sul da barra de Cananéia a leste da Ilha Cardoso. Antônio $P$. de Almeida, "Bom Abrigo" Revista do Instituto Histórico e Geográfico de São Paulo, vol. XXXIV, pp. 43 e 60 . "Della ainda hoje restam os antigos paredões e o próprio forno com o seu caldeirão de ferro, destinado à fabricação do azeite", p. 63. Foi certamente um estabelecimento de reduzidas proporções, sem dúvida sucursal de uma armação mais importante, existente no litoral da Capitania de São Paulo.

(29). - "Armações...", por Luís de França Almeida e Sá, op. cit., pp. 190 e 191.
} 
Valiosa é a descrição da armação de Itapocoróia feita por Saint-Hilaire, quando lá esteve, em seu relato "Viagem à Província de Santa Catharina", em 1820.

A enseada de Itapocoróia (30) se estende da ponta do morro do Cambri à do Morro da Vigia, formando no litoral catarinense uma larga reentrância semi-circular.

No fundo da enseada, nas proximidades do morro do Cambri, foi construída, em 1778 a Armação de Itapocoróia. Diz Saint-Hilaire que eram vastas as construções. A casa do administrador, ou "Casa Grande", a capela, a moradia do capelão situavam-se em terreno mais elevado, junto a um outeiro. $O$ alojamento dos pescadores erguia-se à beira-mar. Ali se instalavam com suas mulheres, na época das pescarias.

Além da "Casa Grande", havia também o "Engenho de frigir" (...)" $"$ "..) com noventa e um passos de comprimento onde era fabricado o azeite.

No tempo em que o naturalista lá esteve, existiam ainda, de um passado mais próspero, sòmente nove caldeiras com as respectivas fornalhas. Em forma de calota hemisférica, media cada caldeira $151 / 2$ pés inglêses, ou 6 metros e pouco de circunferência.

Atrás do "Engenho de frigir" havia outro compartimento com as mesmas dimensões, dividido em sete reservatórios para os quais, por meio de calhas escoava o óleo das caldeiras. Eram os reservatórics construídos de tijolo, com 13 passos de comprimento e capacidade eqüivalente a 10 pipas, cada um.

Ainda, junto à praia, em frente a um pátio quadrado, erguiamse os armazéns e as habitaçōes dos negros.

Dos apetrechos destinados à pesca do cetáceo, Saint-Hilaire menciona as lanchas, pontudas nas extremidades, assemelhando-se a lançadeiras. Dispunha, cada uma, de seis bancos para os remadores e podiam desenvolver grande velocidade.

Quando saiam para a pescaria, era cada uma seguida de outra, a "lancha de socôrro", destinada a rebocar as baleias mortas para a praia e indispensável em casos de emergência. Isto, devido aos imprevistos que puslessem advir da perigosa atividade.

Seus tripulantes recebiam propinas e o capelão, da praia, abençoava as embarcações à hora da partida para a pesca.

\footnotetext{
(30). - Segundo Teodoro Sampaio, Itaposoróia significa "lage que emerge, rochêdo que sobressai". Em 1811 ai existia um povoado, com 1417 homens livres e 223 escravos, uma escola primária e uma Igreja consagrada à Nossa Senhora da Penha. Foi elevado a freguesia em 1839. Augusto de Saint-Hilaire "Viagem à Província de Santa Catarina (1820)", p. 129, nota 12, e pp. 137 e 138 .
} 


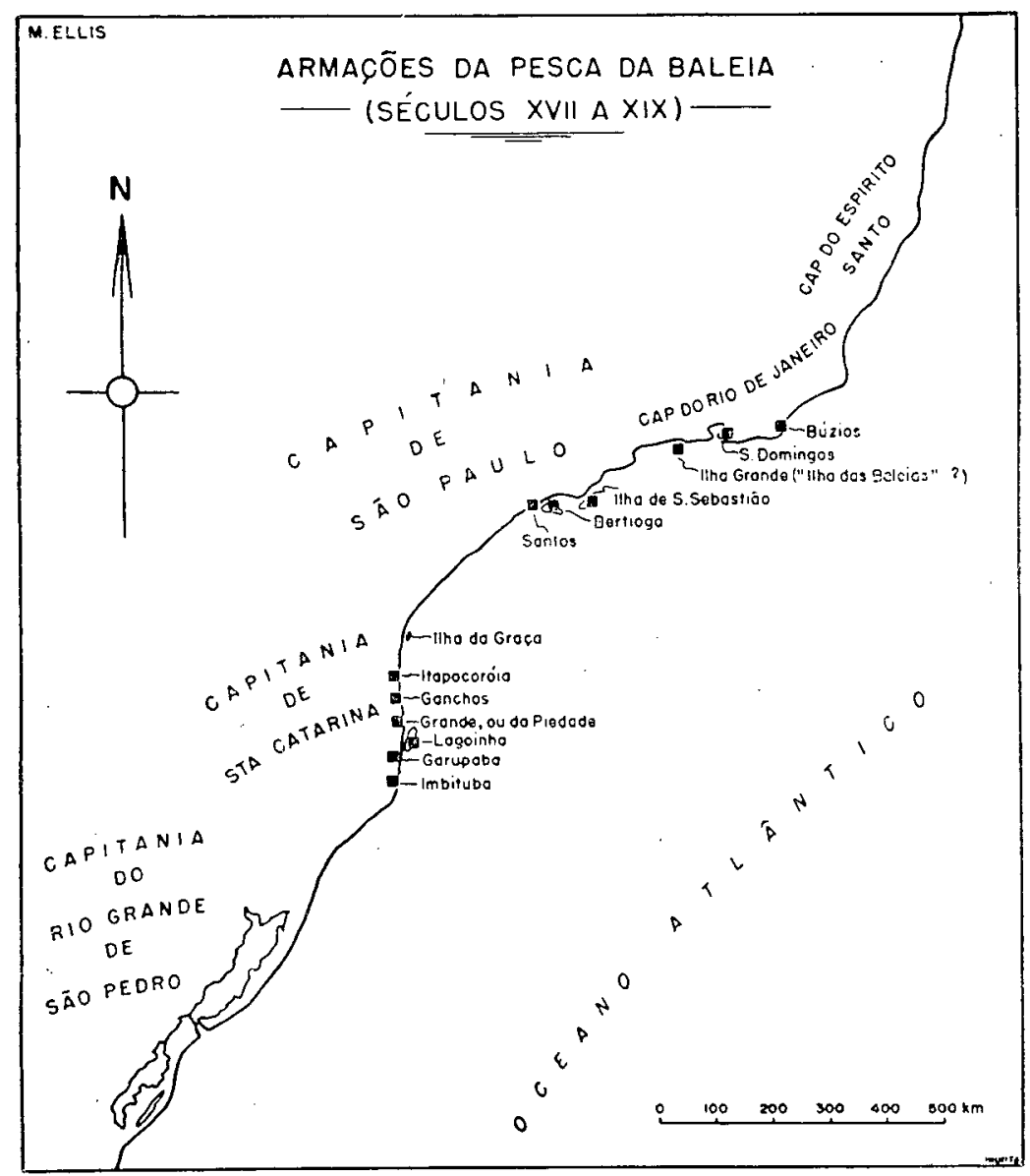

Fig. 1. - Principal área das armações da pesca da baleia na costa do Brasil (Séculos XVII a XIX). 


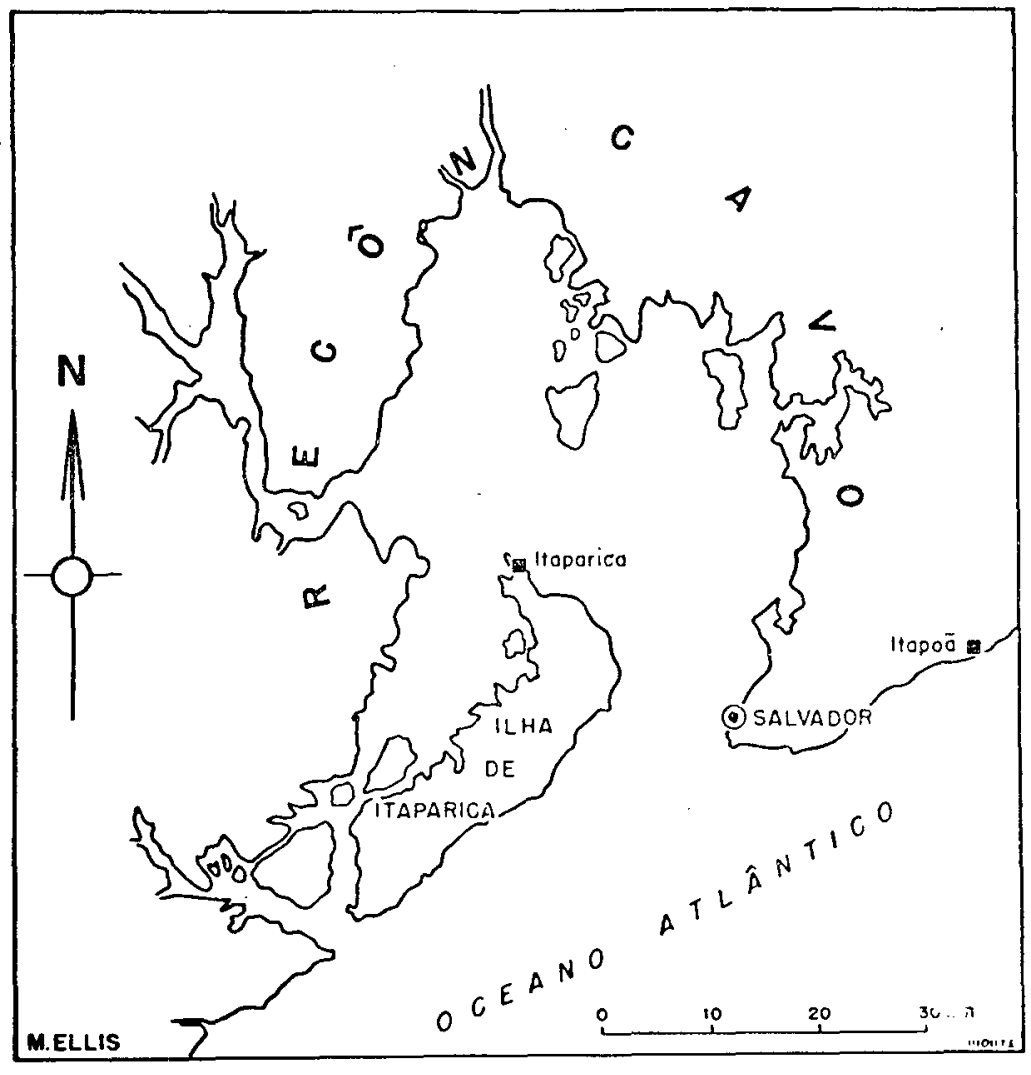

Fig. 2. - Armaçồs de Itaparica e Itapoã, na Bahia (Séculos XVII a XIX). 
O jato de vapor de água emitido pela baleia ao respirar indicava a sua presença. A lancha se aproximava do mamífero e, sem barulho, o baleeiro arremessava-1he o arpão.

Arpoada, transpassada pelas lanças e morta, a baleia rebocada para a armação, era ali colocada de costas entre dois estrados, sôbre dois trapiches. O toicinho, cortado em tiras e transportado para o "engenho de frigir", era reduzido a postas, sendo então lançadas nas caldeiras para se derreterem. Desprendida a gordura; as postas mergulhavam no óleo, sendo retiradas do fundo das caldeiras e depois passadas por uma prensa. Os resíduos ou torresmos, eram queimadios nas fornalhas.

Pronto o azeite, colocado em barris, ia para o Rio de Janeiro. Cada baleia produzia de 12 a 20 pipas.

As "barbas" atiradas a um tanque circular, depois de algum tempo delas eram extraídas as lâminas que as constituiam, ou barbatanas.

$\mathrm{Na}$ fabricação do azeite de baleia trabalhavam os escravos: A pesca, entretanto, era praticada por homens livres, pagos à base do número de animais pescados.

$\mathrm{Na}$ época em que Saint-Hilaire lavrou o seu depoimento, os componentes das guarnições de tôdas as lanchas recebiam a mesma quantia que os da embarcação arpoadora, embora fôsse pescada uma só baleia.

De cada uma, cabia aos arpodoares a soma de $3 \$ 000$, aos patrões"dos barcos de pesca, $1 \$ 000$, aos das lanchas de socôrro $\$ 800$, e aos remadores, na mesma proporção.

Os homens que se dedicavam àquelas atividades, por via de regra pobres agricultores, quando terminava a época da pescaria - de junho a meados de agôsto - não voltavam imediatamente ao trabalho da terra. Dispendiam mal o dinheiro ganho, entregando-se à indolência, bebendo, tocando viola e cantando, até esvaziarem completamente os bolsos.

Em 1820, quando o sábio francês esteve na armação de Itapocoróia, havia muito que declinava a produção resultante da pesca da baleia em contínua decadência, desde fins do século XVIII. São suas estas palavras:

"Desde então, era fảcil prever que êsse estabelecimentos e os demais do mesmo gênero não poderiam subsistir por muito tempo. Assim mesmo, parece. que ainda puderam manter-se por alguns anos após minha viagem $(\ldots)^{\prime \prime}$.

Tempos depois, da armação de Itapocoróia só restariam vestígios.... (31).

(31). - Auguste de Saint-Hilaire, op. cit. pp. 129 a 138 . 
Saint-Hilaire também visitłu, na mesma época, a armação de Garupaba (32) ao sul da Ilha de Santa Catarina, na enseada de Brito (33), baía estreita e comprida, cercada de morros revestidos de mata.

Inferior à armação de Itapocoróia, também dispunha de Igreja, moradias do administrador, do capelão e dos feitores, construídas na encosta de um morro. O "engenho de frigir", os reservatórios e os alojamentos dos negros localizavam-se à beira da enseada (34).

Menos importante do que as precedentes era a armação de Imbituba, também mencionada por Saint-Hilaire, em sua viagem pelo litoral de Santa Catarina.

Localizada no interior da enseada de Imbituba, têrmo da vila de Laguna (35), era a última daquela costa. Suas dependências eram baixas e ficavam à beira mar (36).

Triste quadro de uma armação de baleias em decadência no litoral catarinense deixou-nos Carl Seidler, o mercenário alemão a serviço do primeiro Reinado.

Em meados da segunda década do século XIX, encontrava-se em Destêrro, engajado num batalhão de caçadores, dos seis que lá estavam. Devido à falta de acomodações para os soldados, cada dois meses, deveria um batalhão se alojar na armação de baleias, situada a sete léguas daquela capital. Ficava a armação no continente.

Para chegar até ela, era preciso navegar em botes pelo estreito que separa a Ilha de Santa Catarina da terra firme de

“(..) 300 a 400 passos de largura (..)", marchar “(...) até a insignificante cidadezinha de São Miguel $(\ldots)$ " e dəpois até a armação, " (...) de aspecto triste, deserto".

Pelas indicações fornecidas por Seidler, na sua marcha, de Destêrro até a armação, é possível identificá-la com a armação Grande, ou da Piedade, fundada em 1746, aproximadamente, na barra norte da Ilha de Santa Catarina, no distrito da freguesia de São Miguel (37).

Era

"(...) tudo quanto havia de ruim (..)", aquela " (...) famigerada cova do inferno (...)" que àtigamente rendera à Corôa portuguêsa ànualmente a soma de “( .. 400.000 piastras espanholas".

(32). - Do guarani, "Ygacupa", a enseada dos barcos, A. Saint-Hïhire, op. cit., p. 203 .

(33). - Pizarro e Araújo, op. crit., vol. 9.0, p. 268

(34).- A. Saint-Hilaire, op. cit., pp. 208, 209.

(35). - Pizarro e Araújo, op. cit., vol. 9.0, p. 268.

(36). - A. Saint-Hilaire, op cit., p. 212. Segundo Teodoro Sampaio, Imbituba ou

(37). - Ver o que foi dito no início do Capítulo sốbre essa armação. 
Sob o assoalho das amplas construçōes existiam vazias,

“(...) grandes abóbodas de alvenaria, onde se guardava o azeite das baleias até que houvesse quantidade bastante para embarcar nos navios" (38).

Havia oito ou dez anos que o resíduo de óleo deteriorado,

" (...) com espessura de um pé, restava ali (...)" rescendendo e espalhando " $(. .$.$) atraves das juntas aber-$ tas (...)" um " $(\ldots)$ cheiro repugnante que empestava tôda a redondeza".

Não existia viva alma, a não ser o Administrador e alguns negros velhos, antigos escravos da armação, já centenários, que perambulavam pelas instalações: um edifício amplo; longo, cercado de alto muro

"(..) e dividido em dois quadros iguais (..)", alguns ranchos isolados " $(\ldots)$ pois não se podiam chamar de casas, visto que no mínimo uma casa exige porta e janela, telhado e divisão interna".

Além dos negros encanecidos e decrépitos, habitavam as dependências da armação,

$$
\text { (...)", (..) ratos, formigas, cobrinhas escorregadias }
$$

enxames de pulgas e de bichos de pé.

(38). - John Mawe de sua visita à Santa Catarina, legou-nos curiosas notas sôbre uma armação de pesca de baleias no litoral catarinense, notas essas que foram publiçadas nas "Viagens ao Interior do Brasil, principalmente aos distritos do ouro e dos diamantes" cuja primeira edição data de Londres em 1812.

Embora o Autor nāo identificasse a armaçāo, conseguimos localizá-la, através das referências geográficas apresentadas. Era a Armaçāo da Piedade, a mesma visitada por Seidler anos depois.

Localizava-se na extremidade de uma baía, distante nove léguas de São José e quatro de Santa Cruz.

Impressionou-se, Mawe, com os "molhes" que se estendiam "pelo mar a dentro", "numa profundidade de dezoito a vinte pés", apoiando "cabrestantes" e "guindastes" e mais "máquinas necessárias" com "a casa da caldeira" que alojava vinte e sete caldeiras enormes $e$ com os tanques "enormes reservatórios em forma de abóboda em alguns dos quais um bote pode mover-se com facilidade".

Disse ainda que conseguiu observar tudo graças à gentileza do Comandante Capitão Jacinto Sāo Jorge (sic) que ali vivia "principescamente, dono de vasta propriedade por êle franqueada com grande espírito público liberalidade". J. Mawe, op. cit, pp. 63, 64 .

Ver também, F. Denis - "Brésil", p. 174 - Há referência a uma armação também nāo identificada, em Santa Catarina, cuja descrição se assemelha à da Piedade em alguns aspectos. "Cette usine, propre a fondre le lard du cetacé est, sans contredit, la plus belle et la plus vaste qui éxiste au Brésil, puisque l'espèce de citerne où l'on renferme l'huile permettrait à une petite embarcation de se mouvoir aisément. Mais en même temps, il est probable que de tels établissements, bâtis sur des dimensions colossales, ont perdu une partie de leur importance (...)". E' uma informação de Langsdorf segundo $F$. "Denis, "(..) trop peu connue en France (...)". 
Decrépitos os escravos, decrépita jazia a armação Grande ou da Piedade. Ia longe o tempo da pesca de 400 a 500 baleias anuais....

Agora não havia rendimento suficiente para pagar o administrador, sustentar e substituir os escravos. E' que

" (...) o govêrno intimidado pelo aspecto econômico deixara de importar-se com a armação (...)" parecendo “(...) firmemente resolvido a deixar decair completamente esta improdutiva instalação" (39) .

$O$ estado de decadência em que se encontrava a armação da Piedade, na época em que Carl Seidler a visitou, testemunha a agonia de uma das fontes de renda do Brasil Colonial.

O período áureo da pesca da baleia já pertencia ao passado... 


\section{V. - O FIM DO MONOPÓLIO REAL DA PESCA DA BALEIA NO BRASIL.}

Os fatôres da extinção do monopólio. A decadência da pesca. A "Memória" de José Bonifácio de Andrada e Silva. As deficiências técnicas no preparo do azeite de baleia. A influência da Academia Real de Ciências de Lisboa.

Quando o alvará do Príncipe Regente, datado de 24 de abril de 1801 (1), extinguiu o regime de contratos, a pesca da baleia no Brasil já havia entrado em decadência.

Muitas das antigas armações tinham sido abandonadas por inúteis devido à grande diminuição do número de cetáceos (2). A de Cabo Frio era um exemplo de inutilidade.

$$
\text { “ }(. .) \text { assás reconhecida }(\ldots) \text { " (3). }
$$

Durante o último contrato arrematado por Joaquim Pedro Quintela, em 1789, pelo prazo de doze anos, a pesca fôra reduzida e os lucros diminutos, tornando-se problemática a sua arrematação. Foi quando D. João suspendeu o monopólio.

Pescadores de baleia inglêses e norté-americanos, senhores de técnicas mais aperfeiçoadas na pesca e na produção do azeite, prejudicaram sem dúvida alguma, os rendimentos daquela indústria no litoral do Brasil.

Jacome Ratton, nas suas "Recordações (..$)$ " (4), refere-se ao fato dos Contratadores terem abandonado o

“(..) iniportante ramo (...)" de negócio, em proveito dos inglêses e norte-americanos que passaram então a explorá-lo, não cessando “ $(. .$.$) de o desfructar”.$

(1). - "Alvará do Príncipe Regente D. João, de 24 de abril de 1801 abolindo 0 contrato do estanque do sal e o da pescaria das baleias", in "Collecção de Legishlução Portuǵtueza desde a ultima compitação das Ordenaçóes, redigida pelo Desembargador Antônio Delǵado da Silva", volume de 1791 a 1801, pp. 694 e segtes.

(2). - Arquivo Histórico Ultramarino de Lisboa, Dócumentos Avulsos do Rio de Janeiro, caixa de 1802 . "Resposta do Desembargador Procurador da Corôa e Fazenda, Francisco de Souza Guerra de Araújo Godinho, do Rio de Janeiro a 4 de abril de 1802 criticando um projeto de estabelecimento de uma Sociedade para a pesca da baleia no Brasil". Anexo n.o 3, ao "oficio de $D$. Fernando José de Portugal ao Visconde de Anadia, do Rio de Janeiro, a 20 de maio de 1802 , enviando planos dos comerciantes do Rio de Janeiro concernentes ao estabelecimento de uma sociedade para a pesca da baleia no Brasil". Cópia. (Manuscrito Inédito).

(3). - Idem, "Resposta às objeçoens do Procurador da Coroa e Fazenda, feita pelos autores $\mathrm{e}$ interessados no plano proposto pelo Secretario e Deputado da Junta ou meza da Inspecçāo. Datada de ' 7 de maio de 1802". Cópia. (Manuscrito Inédito). Anexo no 9 ao anterió citado acima

(4). — "Recordaçōes de Jacome Ratton...", p. '243. 
Entravam em colapso as armaçōes das costas da Bahia, do Rio de Janeiro e principalmente de Santa Catarina. Portugal chegou a adquirir o azeite estrangeiro para abastecer a Marinha Real e Mercante, inclusive para iluminação, como até a importar o sabão inglês fabricado com óleo de baleia! Isto, sem mencionar os demais produtos derivados do cetáceo, como barbatanas e espermacete.

Até pouco tempo tivera o Reino,

“(...) azeite de sobejo para o seu consumo, e para exportar annualmente milheiros de pipas, e grande quantidade de barba de balea, o que tudo hoje compra aos estrangeiros, para o consumo em Portugal, e talves no Brazil; sem fallar do Espermaceti, producto muito attendivel para a fabricação de velas como já se praticou pela administração do Barão de Quintella $(\ldots)$ ”. Tudo “ $(\ldots)$ se deixou perder (...)" (5).

Em ofício de 26 de dezembro de 1801, dirigido a D. Rodrigo de Souza Coutinho, o Conselheiro Chanceler da Relação do Rio de Janeiro, Luís Beltrão de Gouvea de Almeida chamava a atenção do Govêrno português para a concorrência movida a Portugal pelas nações estrangeiras no setor relativo à pesca das baleias. Dizia:

"As Nasçoens Estrangeiras, que fazem esta pesca, vão mais ao sul da nossa America, aonde esperão, pescão, ferem e afugentão o Peixe; e quantos mais Navios vierem da Europa, tanto mais se aumentará a nossa perda" (6) .

Seguramente, o declínio daquela atividade evidenciado pela concorrência estrangeira foi $\circ$ primeiro fator a influir na resolução do Regente. A pesca da baleia não mais permanecendo limitada a certas áreas do litoral brasileiro como o fôra até então, podendo estender-se a outras como também expandir-se para alto mar, sendo livre a todos os que desejassem praticá-la, talvez atingisse a pujança de outrora...

Entretanto, o famoso alvará de 24 de abril de 1801 que suprimiu o privilégio da pesca da baleia e extinguiu o monopólio do sal, não chegou a cogitar dos problemas advindos da técnica mal orientada que presidia, desde o século XVII, a pesca da baleia no Brasil, seguindo princípios de uma economia destrutiva.

(5). - Idem, ibidem.

Na obra de J. B. von Spix e C. F. P. von Martius, "Viagem pelo Brasil" p. 276, nota II, existe uma importante referência aos pescadores de baleia inglêses e norte-americanos: estabelecidos nas ilhas Falkland, aos quais é atribuído o prejuízo dos portuguêses naquela indústria praticada no litoral brasileiro.

(6). - Arquivo Hístórico Ultramarino de Lisbaa. Documentos Avulsos do Rio de Janeiro, caixa de 1802. "Oficio do Conselheiro Chanceler da Relação do Rio de Janeiro, Luís Beltrão de Gouvea a D. Rodrigo de Souza Coutinho, datado do Rio de Janeiro a 26 de dezembro de 1801 , remetendo cópias pelas quais se verá co estado atual da pesca das baleas". Cópia. Anexo a outro ofício de " 29 do mesmo mês e ano. (Manuscrito Inédito). 
Anos antes, porém, alguém já havia estudado amplamente a questão, colocando-a em evidência: José Bonifácio de Andrada e Silva, autor da Memoria sobre a pesca das baleas, e extracção do seu Azeite com algumas reflexões a respeito das nossas pescarias, publicada nas "Memorias Economicas da Real Academia das Sciencias de Lisboa", em 1790 (7), logo após a sua admissão como sócio daquela instituição cultural, a 4 de março de 1789 (8).

0 objetivo de José Bonifácio era demonstrar o interêsse existente na liberação da pesca da baleia e o seu maior aproveitamento econômico, através de uma indústria melhor orientada, com técnicas mais eficientes na extração do óleo e dos outros produtos derivadios do precioso mamífero.

Eis o que diz sôbre o animal, antes de cuidar do problema:

"Cetaceos" que "(..) servem na pasmosa cadea animal de nó que ata os quadrupedes aos peixes".

Realmente, pela forma da cabeça aumentando a superficie de contacto do corpo, "(...) em hum dado volume de agua $(\ldots)$ " diminuindo " $(\ldots)$ a pressão e a resistencia (...)" pela cauda musculosa apta a dirigir os movimentos rapidos, pelas barbatanas lateraes que funcionam como remos, durante muito tempo, haviam sido as baleias confundidas com os peixes. Entretanto, as suas funções orgânicas provam o contrário; " $(\ldots)$ seu sangue abundoso, e quente; o coração de dous ventriculos; a respiração pelo bofe; a geração; e modo de criar seus filhos; a grossa camada de gordura porosa e tendinosa;

(7). - Tomo II, pp. 388 e segtes.

(8). - Santos ainda era uma vila, quando lá nasceu Josá Bonifácio de Andrada e Silva, a 13 de junho de 1763 . Foi onde recebeu instrução primária, sob a direção do pai, o Cel. Bonifácio: José de Andrada, homem de espírito e bastante instruído em relação ao tempo em que vivia. Aos catorze anos, iniciou em São Paulo os seus estudos preparatórios para os cursos superiores, sob os cuidados do Bispo Metropolitano, D. Frei Manuel da Ressurreição, qué, à própria custa, mantinha aulas para o ensino de Lógica, Metafísica, Etica, Retórica e Francês. Dos 17 aos 20 anos, permaneceu José Bonifácio no Rio de Janeiro, de lá partindo, em 1783 para Lisboa, com destino a Coimbra, onde se matriculou na Faculdade de Direito e na de Filosofia Natural. Em 1787, conquistava a diploma de Bacharel em Filosofia e o de Bacharel em Direito Civil depois de brilhante curso. Em 1789, entrava para a Real Academia das Ciências de Lisboa. Logo depois, apresentava o valioso estudo, "Memoria sobre a pesca das baleas (...)". Nessa época já era grande o prestígio intelectual do futuro estadista. Por indicaçāo de seu protetor, o Duque de Lafóes, foi comissionado pelo govêrno para aperfeiçoar, em outros países da Europa, o notório patrimônio cultural de que já dispunha. Em junho de 1790 , partia para a França, para conviver com os mais eminentes sábios, como Jussien, Chaptal, Fourcroy e Haiiy. A França era então um centro de renovação científica. Esteve, em seguida, na Alemanha, Austria, Itália, Inglaterra, Suécia, Noruega, Bélgica, Holanda a se aperfeiçoar e a adquirir maiores conhecimentos.

Em 1800, regressava a Portugal, para concretizar o que aprendera... Em junho de 1812 foi escolhido por unânimidade para o pósto de Secretário Perpétuo da Academia Real das Ciências de Lisboa, à testa do qual esteve até regressar ao Brasil, em 1819. Durante êsse período, contribuiu com o seu talento para o grande progresso dos trabalhos daquela agremiação cultural. Alberto de Sousa op. cit, vol. I, pp. 338, 341, 343, 345, 347, 348, 355. Ver também, Elysiário Távora Filho, "José Bonifácio Cientista, Professor e Técnico", pp. 12 e segtes. 
a mesma posiçằ da sua cauda; os espiraculos da cabeca; em fim, a estructura de suas barbatanas lateraes com ossos articulados á maneira da mão humana; tủdo isto de commum com os quadrupedes as aparta de necessidade da classe dos peixes" (9).

A espécie pescada no Brasil, segundo José Bonifácio, possuia ventre liso, três barbatanas, os maxilares iguais e agudos; classificou-a o Andrada, como a baloena physalus de Linneo (10).

Segundo José Bonifácio, a pesca da baleia estabeleceu-se no Brasil em 1615, iniciada pelos portuguêses. Para obter uma renda certa, a Corôa fêz dela monopólio de Estado.

Entretanto, o desenvolvimento daquela atividade necessitava

$$
\text { (...)" "...) do aguilhão da emulação e concorrencia }
$$

A pesca, livre aos particulares, cada um teria interêsse em aperfeiçó-la e ampliá-la, não se conservando aquela indústria

$$
\text { “( ...) em tão fatal imperfeição" (11). }
$$

Conseqüentemente o monopólio teria funcionado como um entrave ao desenvolvimento da pesca da baleia no Brasil.

E' o que demonstrou mui discretamente o então jovem Andrada (12).

Por sua vez, a técnica da pesca e da exploração dos derivados da baleia foi desenvolvendo e acentuando a decadência da indústria com o correr dos anos.

Além disso, eram os feitores das armações autoritários, pretenciosos e ao mesmo tempo

“(...) estupidos, e inteiramente ignorantes na arte de pescar baleas, e modo de extrahir o azeite (...)" e, “ (...) teimosamente crêm não podêrem dirigir-se melhor

\footnotetext{
(9) - José Bonifácio de Andrada e Silva, op. cit., pp. 395, 396.

(10). - Idem, p. 396. Cita o autor oito qualidades de baleias: "(..) a grande balea da Groenland (Baloena mysticetus de Linneo); o Nord Kaper dos inglezes (Baloen. glacialis de Bonaterre); o Fin fish (Baleon, physalus de Linn); o Tiampon (Baloen. Nodosa de Bonaterre); o Humback Whale (Baloen. gibbosa do mesmo), a Jubarta (Balcen, boops de Linn.); o Rorquel (Baloen, musculus do mesmo); e a balea bicuda ou rostrata de Fabrício, difficultoso me he em verdade affirmar qual seja destas especies a que se pesca no Brasil; comtudo parece-me provavel ser a Baloena physalus de Linneo, porque, segundo a minha lembrança, tem ella o ventre lizo, tres barbatanas, e os maxillares iguaes e agudos; sinaes que caracterizão esta espécie". A classificação de José Bonifácio discorda da classificação atual.

(11). - J. B. de Andrada e Silva, op. cit., p. 394.

(12). - J. B, von Spix e C. F. P. von Martius, op. cit. pp. 275 e 276, nota II referem-se ao sistema de monopólio praticado por Portugal, como um entrave ao desenvolvimento industrial do Brasil. Na pesca da baleia, por exentplo, aquêle regime praticou a atividade sem cuidar do futuro e tratou do aproveitamento dos produtos da baleia, sem os cuidados e sem as técnicas e o apatelhamento necessários.
} 
estas manoblaś só porque elles as tem dirigido assim à muitos annos (...)" (13).

Ao par do número reduzido de armações no Brasil, circunscritas a certas áreas (14), a pesca era praticada exclusivamente nas barras, não se estendendo os pescadores ao longo do litoral brasileiro e da América espanhola.

O sacrifício dos "baleotes de mama", para maior facilidade no arpoamento das mães, era uma prática destrutiva em relação às gerações futuras, pois, de acôrdo com as leis da natureza, as baleias geram um único filho, de dois em dois anos. Morto o baleote, deixava de contribuir para a proliferação da espécie (15), não podendo oferecer as vantagens econômicas de uma baleia adulta. Os de dois anos, depois de desmamados, emagreciam extraordinàriamente, dando a metade do azeite dos alimentados com o leite materno.

As baleias mortas na época da amamentação, magras, pouco óleo produziam .

Desta forma, diminuia anualmente o número das fêmeas,

“ (...) crescendo á proporção o dos machos, que assim de nada servem" (16).

Esta foi uma das causas pelas quais já se achavam abandonadas as armações da Bahia e do Rio de Janeiro, na última década do século XVIII (17).

Existiam ainda, entre muitas, outras falhas concernentes à pesca da baleia, tais como: excessivos gastos com embarcaçỗes e pessoal muitas vêzes desnecessário; ou proteção injusta a pessoas

(13). - J. B. de Andrade e Silva op. cit., p. 395 .

(14). - "Na costa da Capitania de São Paulo apenas existe a Armação da Britioga, na Villa de Santos. Assim em perto de 80 leguas de costa fertilissima toda ella de baleas, apenas ha huma e esta muito ma1 regulada. Que utilidades se não tiravão do estabelecimento de novas armaçóes nas entradas e barras dos rios e nas bahias, de que abunda toda a costa, onde vai ter immensidade de baleas, que podião ser apanhadas facilmente pelo pouco medo, que tem de se chegarem á terra?". "Memoria", op. cit, p. 397.

(15) . - "Memoria...", pp. 398, 399. "Deve ser certo merecer tambem grande contemplação a perniciosa pratica de matarem os baleotes de mama para assim harpoarem as miäis com maior facilidade. Tem estas tanto amor aos seus filhinhos, que quasi sempre os trazem entre as barbatanas para lhes darem leite; e se por ventura lhos matão, não desampárão o lugar, sem deixar igualmente a vida na ponta dos farpóes: he seu amor tamanho, que podendo demorar-se no fundo da agua por mais de meia hora sem vir respirar assima, e escapar assim ao perigo, que as ameaça, folgão antes expor a vida para salvarem a dos filhinhos, que não pode estar sem respirar por tanto tempo. Esta ternura das mãis facilita sem duvida a pesca: e o methodo de matar primeiro os baleotes pequenos para segurar as mãis, que enraivecidas muitas vezes virão as lanchas parece visto a vulto excellente, mas olhado de perto he máo, e trará consigo, a não se prover nisso, a ruina total desta tão importante pescaria. He fóra de toda a duvida, que matando-se os baleotes de mama, vem $I$. deminuir-se a geração futura (...)".

(16). - "Memoria...", p. 400 .

(17). Ibidem, p. 400 . 
sem prática para o exercício daquela atividade. Administradores do Rio de Janeiro, por

" (...) empenhos indiscretos e injustos, ou interesse seu proprio (...)", supriam as lanchas das pescarias, " (...) com afilhados sem prática, e pretos buçaes, que servem meramente de embaraçar aos outros companheiros" (18).

E, remeiros, timoneiro e arpoador eram os elementos decisivos do sucesso e do lucro da pescaria da baleia (19).

Isto tudo, sem falar nas deficiências do equipamento de pesca das armações, como arpões, lanças, ganchos, aparelhos necessários ao corte do toicinho e embarcações e de numerosos erros praticados no sistema adotado para as pescarias (20).

As falhas e os desleixos cometidos no setor técnico do aproveitamento do toicinho e da extração e conservação do azeite da baleia, também conspiraram para a decadência da pesca do valioso cetáceo. Eis alguns exemplos. Desperdício da gordura no retalhamento da baleia, pelo desprêzo de certas porções de carne, ao serem cortadas as duas grandes

$$
\text { da (...)", talhadas lateraes, que dos olhos vão até á cau- }
$$

bem como das banhas e da língua. Os "baleotes de mama" também deixavam de ser aproveitadios, embora derretessem com facilidade ao calor do fogo, dando excelente azeite. Se de cada baleia fôssem racionalmente aproveitadas tôdas as partes que produzem azeite, cada uma daria 20 pipas, em vez de 14 ou 15 sòmente.

Ainda mais. Quando eram pescadas muitas baleias, na impossibilidade de serem retalhadas de uma vez, boa parte delas permanecia a apodrecer nas praias.

Um Contratador da pesca da baleia no Brasil, Tomé Gomes Moreira, chegou ao extremo de mandar pescar os cetáceos com o fim de obter ùnicamente as barbatanas, abandonando os enormes cadáveres pelas praias, e deixando-os apodrecer ao ar livre a empestar o ambiente com

$$
\text { “(...) um cheiro nauseabundo" (21). }
$$

(18). - Ibidem.

(19). - Ibdem. p. 400 .

(20). - Ibidem p. 401

(21). - Arquivo Histórico Ultramarino de Lisboa. Caixa de documentos do Rio de Janeiro de 1749-1750 — "Representação dos oficiais da Câmara de São Paulo a D. João $V$, pedindo providências para defender os seus moradores de alguma peste, derivada da maneira como o contratador das baleias Tomés Gomes Moreira manda matar aqueles cetáceos a fim de sòmente 1hes extrair as barbatanas, deixando os corpos intactos espalhados pelas praias em grandes distancias, e aos rigores dos tempos apodrecendo e exalando um creiro nauseabundo. Santos, em Câmara, 24 de dazembro de 1748". (Manuscrito). 
Freqüentemente, os escravos encarregados de frigir as postas de toicinho fresco das baleias, para a fabricação do azeite, cortavam-nas maiores do que o necessário, gastando muito mais tempo para frigi-las, impedindo que produzissem todo o azeite que continham ou provocando a queima do óleo sob a demorada ação do fogo (22).

Da inútil quantidade e da má construção - no sentido de aproveitamento do fogo - das fornalhas destinadas a fundir o toicinho das baleias, advinham também muitos prejuízos ao contrato (23). Devoravam as fornalhas o máximo possivel de lenha para aquela operação.

Com isso, muitas vêzes o azeite se queimava nas caldeiras, decompondo-ste como conseqüência e exalando mau cheiro. Kesíduos ou "borras", mucilagem animal precipitada pelo calor, depositavam-se no fundo daqueles tachos, aumentando depois, nos tanques e barris. O azeite continuava a decompor-se, tornando-se rançoso e espêsso, adquirindo cor escura e cheiro cada vez mais desagrađável,

$$
\text { “(..) ainda depois de extrahido (...)" (24). }
$$

Com o grande consumo de lenha, o contrato se encontrava anualmente na absoluta necessidade de adquirir terras revestidas de matas, concorrendo, desta forma, para a destruição de grandes áreas florestais, cuja madeira era utilizada, na época das pescarias, dos fins de junho a meados de agôsto (25).

Ao problema resultante da má construção das fornalhas que não trabalhavam no sentido do máximo aproveitamento do fogo, somava-se o da multiplicidade de caldeiras, de cujas reduzidas dimensões, advinham o exagerado consumo de lenha, o maior desgaste do escravo negro e a freqüente queima do óleo,

"(...) pelo augmento das superficies, a que as talhadas se apegão (...)", bem como “(..$)$ maior custo das mesmas caldeiras" (26).

Além disso, não eram as "talhadas" da baleia viradas nas caldeiras durante a fritura, com colheres ou pás de ferro próprias pa-

(22). — "Memoria...", p. 403

(23). - Ibidem, pp. 404, 405.

(24). - Ibidem pp. 406, 407 .

(25). - Ibidem, p. 407 .

(26). - Ibidem, p. 408. "Nas Fabricas Estrangeiras não passão commumente as caldeiras de duas, ainda nas maiores; e algumas ha que tem huma sómente: mas na Armação de Santa Catharina ha pouco mais ou menos 20 de 4 palmos de diametro unicamente; e o peor he que cada qual tem sua fornalha á parte, em que se gasta muita lenha baldada, por sahir todo o lume para fóra; e este he tão desmarcado, que logo queima o torresmo, sem que o mesmo pela codea espessa, que adquire, possa soltar todo o azeite que contém; e o que sahe vem demais a mais queimado, negra e com fedor". 
ra a separação do toicinho das partes fibrosas da carne, as quais o impediam de se derreter totalmente. Nem funcionavam escumadeiras apropriadas para limpar o azeite dos torresmos, evitando que fôssem ao fundo e se queimassem. Eram êles postos a escorrer numa mesa inclinada para que o óleo fôsse ter a uma calha ligada ao depósito geral do azeite destinado a ser armazenado em pipas. O óleo que escoava dos torresmos carregava pedaços queimados favoráveis à sua fermentação e decomposição.

Mal coado e mal purificado, passava o azeite para o "tanque", onde permanecia por muito tempo em contacto com o ar e sem os necessários cuidados higiênicos, que evitavam o ranço e o mau cheiro (27).

Era êste o defeituoso método empregado, mesmo nas grandes armações do Brasil Colonial para a obtenção do óleo de baleia. Sem dúvida haveria de contribuir para a decadência daquela indústria, influindo, por sua vez, na decadência da pesca.

Pouco tempo depois do estudo de José Bonifácio, diria Luís dos Santos Vilhena, ao escrever sôbre o comércio do azeite de baleia na Bahia:

“(...) grosso como lôdo, feito de torresmos das Balleas (...)" mandado refrigir, era vendido pelo Administrador do Contrato do Sal e do Azeite, “( ...) com a penuria mais escandaloza que pode imaginar-se (...)" (28).

\%

A decadência d'a pesca da baleia no Brasil Colonial resultando dos fatôres apontados acima, sem dúvida provocou a supressão do monopólio real è dos contratos.

Facultada a todos, surgia a esperança de que fôssem supera: das as deficiências técnicas daquela indústria, pela concorrência que os exploradores particulares pudessem mover entre si no setor da pesca e da fabricação do azeite .

Era necessário o

$$
\text { “( } \ldots \text { ) aguilhão da emulação e concorrencia ( ....)" }
$$

đissera José Bonifácio no seu acurado estudo, publicado em 1790; "Memória sôbre a pesca das baleias...", o qual certamente influiu na resolução decorrente do alvará do Príncipe Regente, de 24 de abril de 1801, liberando o comércio do sal e aquela pescaria.

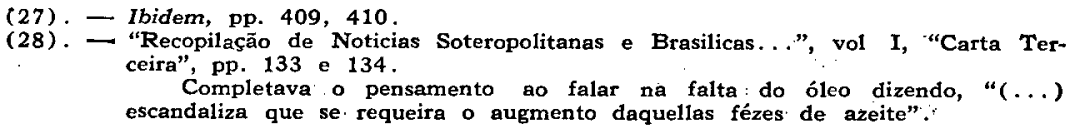


- Se as condiçóes deficientes em que se realizava a pesca e a "Memória..." de José Bonifácio influiram na extinção do privilégio real, outros fatôres importantes também cooperaram naquele sentido.?

$O$ advento do reinado de $\mathrm{D}$. Maria I, em 1777, marcou para Portugal o início de uma nova éra política, na qual o Reino procurou acompanhar o grande movimento de renovação cultural em desenvolvimento na Europa da época (29). Começavam a ser ultrapassadas as tendências mercantilistas. Portugal dos fins do século XVIII recebia e absorvia as idéias influenciadas pelos princípios fisiocratas franceses e pelos da escola inglêsa de Adam Smith.

Eis porque a tendência político-econômica do reinado de $\mathbf{D}$. Maria I foi promover e ampliar a produção em Portugal e principalmente a produção agrícola colonial e as atividades relacionadas à exploração dos produtos regionais para o incremento do comércio metropolitano. Era preciso substituir a mineração em declínio no Brasil no findar do século XVIII (30).

O movimento de renovação cultural em Portugal teve por sede a Academia Real das Ciências de Lisboa, criada por aviso régio de 24 de dezembro de 1779 . Foi seu primeiro presidente, $D$. João de Bragança de Sousa e Ligne, o segundo duque de Lafões, membro da família real portuguêsa. Regressava a Portugal, no início de 1779, depois de longo exílio, durante o período pombalino, em que percorrera as mais notáveis côrtes européias, conviverido com uma elite de pensadores, cientistas e escritores. Trazia um grande cabedal de conhecimentos e dé idéias em voga pela Europa. Foi êle o centro do novo movimento intelectual, congregando os espíritos cultos do Reino. Assim nasceu a Academia Real das Ciências de Lisboa, irmã das Academias de Londres, Paris e Madrí, tendo em mira estudar e difundir os vários ramos do saber - Literatura, História, Ciências Naturais, Agricultura - e cuidar de problemas econômicos e sociais de tôda ordem.

Alguns de seus componentes: Domingos Vandelli, Botelho de Lacerda, D. Rodrigo de Souza Coutinho, Lacerda Lobo, José Bonifácio de Andrada e Silva e muitos outros nomes que encerravam um patrimônio de tradição social e de prestígio intelectual.

D. Maria I era a protetora da instituição (31) que abriu

\footnotetext{
(29). - Caetano Beirão, "D. Maria I, 1777-1792", p. 244.

(30). - Myriam Ellis, op. cit., p. 201.

(31). - Caetano Beirāa, op. cit., pp. 231-234.

Ver também, Antốnio Ferrão, "A Academia das Sciencias de Lisboa e o movimento filosófico scientifico e economico da segunda metade do século XV'III. Academia das Sciencias de Lisboa, Separata do "Boletim da Classe de Letras", vol XV.
} 
“( $(\therefore)$ anualmente os seus concursos para a solução das mais importantes questões de física, quimica, biologia, agricultura, indústria, comércio $(. . .)^{\prime \prime}$,

preocupando-se com o povoamento do Reino, com problemas sociais, econômicos e financeiros, distribuindo prêmios e sementes aos laviradores e enviando pelo país afora instruções para melhoria do cultivo dos campos (32).

Como testemunhas dessas atividades legou à História a Academia as suas "Memórias", entre as quais as importantes "Memórias Econômicas", reunidas e publicadas em 6 volumes, no ano de 1790 .

"Memória", ou informação, como objeto de estudo de um problema, visando a uma solução, ou melhoria de condições existentes, foi um gênero literário muito usado na época, tanto em Portugal como no Brasil. Tinham por costume, os leais suditos, por êsse meio informar Sua Majestade sôbre os problemas do Estado, tratando de propor as soluções julgadas mais eficientes. São exemplos: a "Memória sobre o estado actual da Capitania de Minas Gerais, por José Eloi Ottoni, estando em Lisboa, no anno de 1798" (33), a "Memoria que José Manuel de Sequeira Presbítero Secular Professor Real da Filosofia Racional e Moral da Vila de Cuyabá, acadêmico da Real Academia das Sciencias de Lisboa enviou à mesma Academia sobre a Decadencia actual das tres capitanias de Minas e os meios d'a reparar; no anno de 1802" (34) ou a "Memoria sobre a verdadeira Influencia dias Minas dos $\mathrm{Me}$ taes preciosos na Industria das Nações que as possuem, e especialmente da Portugueza", de D. Rodrigo de Souza Coutinho (35) e outras mais, que proliferaram no reinado de D. Maria I sob o incentivo da Academia Real das Ciências de Lisboa.

Do espírito de renovação econômica e científica da época de D. Maria I, da inteligência e da ampla cultura de José Bonifácio de Andrada e Silva e da situação do Brasil em fins do século XVIII, requerenda $a_{2}$ desenvolvimento de atividades que suprissem a mineração em declínio, nasceu a "Memoria sobre a pesca das baleas e extracção do seu Azeite, com algumas reflexp̃es al respeito das nossas pexcarias". Nasceu à sombra protetora da Academia Real das Ciências de Lisboa. Sem dúvida alguma, repercutiu na extinção

(32). - Antônio Fetrāo, op. cit., pp: $42,43$.

(33). - "Annaes da Biblioteca Nacionar do Rio de Janeiro, vol. XXX, p. 908

(34). - In Sérgio Buarque de Holanda, "Monções", p. 220.

(35). - In "Memorias Economicas da Academia Real das Sciencias de Lisboa (...)" tomo II, pp. 237 e segtes. 
da exploração-exclusivista da pesca das baleias no Brasil Colonial, em 1801 (36).

(Continua no próximo número).

\section{MYRIAM ELLIS}

Assistente da Cadeira de História da Civilização Brasileira da Faculdade de Filosofia, Ciências e Letras da Universidade de São Paulo.

(36). - O V'sconde de Pôrto Seguro, na "História Geral do Brasil", tomo v, p. 17. diz que José Bonifácio pugnou pela abolição do monopólio da pesca da baleia. no Brasil, juntamente como bispo D. José Joaquim da Cunha de Azeredo. Coutinho que também pugnou pela extinção do estanque do sal. 